Eldar Veremchuk

UDK 811.111'373

Zaporizhzhia National University

DOI: $10.4312 /$ vestnik.13.191-206

Ukraine

eldar.veremchuk@gmail.com

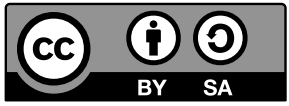

\title{
PROFILING OF THE ETHICAL CONCEPTS GOOD / EVIL AND JUSTICE FROM THE ETYMOLOGICAL PERSPECTIVE
}

The main goal of contemporary cognitive science is to explain how the human mind classifies and categorizes objective reality and operates with the portions of information it receives. Cognitive linguistics in its turn aims at casting light upon the issues such as why a particular portion of information is objectified by a particular language sign, as explored in Metaphor Theory (Lakoff 1993; Lakoff \& Johnson 2003; Chomsky1997), along with the related principles of categorization (Rosh 1978; Evans 2006); how the meanings of the words are interrelated with each other (Fillmore 1982); and in what way language utterances depict our knowledge of the world (Langacker 1987). It should be noted though that these questions are mutually connected and the borders among them are arbitrary rather than objective, hence the abovementioned references are not limited to just one of them but are rather focused on some of them more specifically.

In this paper we will attempt to discuss some ideas which are related to the first two issues, employing cognitive methodology together with etymological analysis. Therefore, the aim of the paper is to reveal the peculiarities of profiling of the concepts GOOD / EVIL and JUSTICE by means of elucidating their source domains from the etymological perspective. This will fulfil the following objectives: 1) to outline the inner form and imagery of the etymons of the analysed ethical concepts; 2) to determine the etymological source domains for the target ethical concepts; 3 ) to create matrix and edifice models of conceptual profiles of the target concepts.

Contextual actualization quantitative analysis of ethical concepts such as GOOD, EVIL, CONSCIENCE, JUSTICE, HONOUR, DIGNITY, HAPPINESS based on the search engines of the British National Corpus proved that the concepts GOOD, EVIL and JUSTICE appeared to be most frequently actualized, and therefore they became the object of research in this paper, while the subject was their etymological source domains.

We argue that ethical categories appeared as a result of generalizations when, for example, a recurring good deed was conceived as something good in general, or an obligation in a particular situation was generalized to an all-embracing duty. In this way there 
appeared a number of generalized mental images that bear very salient evaluative components and are used as mental templates in classification of the new phenomena and objects. These mental templates serve as reference frames for cognition of the new objects, as it is a matter of the fact that everything can be understood only in relation to something else.

We claim that the appearance of an abstract concept happened as a result of cognitive reinterpretation of the concrete one, therefore the hypothesis of the paper is that ethical concepts are based on the cognitive reinterpretation of the concrete things or phenomena. Therefore, the paper's general objective is to define the ethical concepts' source domains. The results thus obtained, in a certain sense, will contribute to the unravelling of the human cognitive mechanisms.

THEORETICAL PRELUDE

\subsection{General remarks}

At a certain point of history, humans developed abstract ideas that characterize the interpersonal relations and states of affairs in objective reality. In other words, in the picture of the world there appeared such concepts as GOOD, EVIL, JUSTICE, DUTY, etc., which gained communicative relevance, that is the necessity to be lexicalized, even though the corresponding words had not previously existed in the language.

The ethical concepts which required nominative means were already partly formed in the consciousness of the speaker on an empirical basis, and what needed to be done was to find a lingual "wrapping" or "container" for the corresponding meaning. Such nominative means are taken not randomly. Often, driven by the inherent principle of 'language economy', the speaker chooses an already existing nominative unit, the meaning of which is most closely connected to the meaning of the target concept on the basis of associations. The principles of ontological mappings on the synchronic level are described in the Conceptual Metaphor Theory (Lakoff \& Johnson 2003). But we argue that cross-domain mappings also underlie processes of conceptualization diachronically, and such complex abstract ideas as ethical concepts are based on the daily experience and knowledge of concrete things, and therefore basic life experience serves as a source domain for ontological mappings. In order to prove this, it is necessary to determine and analyse the source domains for the target abstract ethical concepts. From a diachronic perspective the source domains are the etymons of the target domain lexicalizers. Therefore, analysis of the inner form of the etymons can cast light upon the principles of classification and categorization of the objective reality and conceptualization of abstract notions and ideas.

The etymology of a word comprises a certain perceptive and cognitive image (Golovenko 2021) that can be further interpreted and yield the semantic development of the language sign. The inner form of the word is defined as the "prime cause" and 
is compared with Buddhist dharma (the basic substance, which constitutes the world), the Upanishads' brahman (Absolute Beginning), and the Taoist Tao, which is the cause of all interactions in the Universe and at the same time "the Way" along which people communicate with each other (Golianich 2007). A. Potebnia viewed the issue of the inner form from a psychological perspective, and posited that the inner form is the centre of the image that appears in mind when a person hears the word, and appeal to this psychological construct (image) enables understanding; inner form is the unity of image of the concept with its representation in the mind (Potebnia 1993). Sphet, interpreting the ideas of V. Humboldt, argues that the image that is coined in the inner form is an indispensable psychological construct that enables understanding (Sphet 2006). Therefore, the inner form of the language sign etymon acts as a source domain for ontological metaphorical cross-domain mapping, and identifies the particular image that underlies understanding of the target concept.

In this paper we will make an attempt to trace the linguo-cognitive mechanisms of lexicalization of the target ethical concepts through the analysis of the source etymological domains, and make an attempt to answer the following question: why are particular lexical units (with the particular etymological images) used to denote particular ethical concepts? Or, in other words, why are particular ethical concepts lexicalized by words with a particular etymological image? But before that we need to clarify the terminology used in the paper.

\subsection{Terminology}

According to the classical cognitive approach (Rosh 1978; Evans 2006), a domain can be represented as a conceptual network (see Scragg 1976) or frame (see Fillmore 1982: 111). A frame is a network of terminals and slots, which actualize certain cognitive traits, for instance, the domain RESTAURANT will contain the terminals "food", "service", "visitors", etc. Each domain comprises smaller units - slots. For the terminal "food" they are names of cuisines, like English, Ukrainian, etc, while for the terminal "service" - entertainment, etiquette etc. Each slot is represented by the lexical units which lexicalize certain cognitive traits of the concept. Taken collectively, conceptual traits make up the cognitive content of the concept. R. Langacker (2000), though, used the term 'domain' to explain the principles of creating language utterances. For instance, in the sentence The lamp is above the desk 'lamp' has primary focal prominence (trajector), as it is the subject of the sentence, while desk - the object - is the landmark (domain), which serves as the reference frame. But in the sentence The desk is below the lamp the landmark and trajector change places. Being inspired by this approach, we suggest that Langacker's ideas can be further elaborated and expanded to the onomasiological sphere. In other words, the principle of trajector / landmark alignment can be useful for the description 
and explanation of the paths of semantic evolution and peculiarities of 'wrapping' the concepts in the lingual form, which is often based on metaphorization. In this way the methodology suggested in this paper can complement the classical Metaphor Theory, described in terms of ontological mappings between the source and target domains.

The essence of trajector / landmark alignment in the onomasiological sense consists in the fact that the cognitive traits of the source domain have associative bridges with the cognitive traits of the target domain in the consciousness of the speaker. We suggest calling those traits that make the basis of metaphorical reinterpretation (traits of the source domain) landmark traits. In other words, landmark is the feature of the source domain (concept-emitter), which is associatively close to the feature of the target concept. Landmark traits are objectified by the verbalizers, which have corresponding landmark semes. The target concept is represented as a profile, which has its own cognitive traits - trajector traits. Under the term trajector we understand the target concept feature, which has primary focal prominence in onomasiological process of lexicalizer coinage. The trajector is thus the most salient cognitive feature of the communicatively relevant concept, seeking lexicalization. Since any newly appeared language sign should be motivated, the trajector trait has to be depicted in the semantics of the target concept verbalizer.

The process of metaphorical reinterpretation and transformation of landmarks into trajectors is called landmark-trajector alignment, which sometimes consists of a number of steps that constitute the derivational or compositional path. This approach is in line with the classical Conceptual Metaphor Theory (Lakoff \& Johnson 2003), which explains the way we cognize the world by means of cross-domain mappings, like "argument is war" or "life is a journey", etc, which normally involve concepts and ideas that coexist on the synchronic sociolinguistic level. The approach, suggested in this paper, is designed to elaborate on the tenets of Conceptual Metaphor Theory and cast light upon the ontological correspondences that underlay the appearance of abstract ethical concepts in diachronic perspective.

Landmark-trajector alignment makes the essence of profiling - shaping the target concept and boxing it into the language form. In Langacker's (2000) original sense, the profile is a part of the conceptual base, which constitutes the meaning of the language sign. The base itself has two scopes: immediate (part of information of the domain, lexicalized by the sign) and maximum (all the information represented in the domain). For instance, for the profile of the lexeme elbow (a joint between arm and hand) the immediate scope is represented by the upper limb, while the maximum scope of conceptual base is the human body.

We argue, though, that these notions can be extrapolated to the onomasiological sphere. Under the term immediate scope of the conceptual base we understand the etymological source domains with the landmark traits, which form the base for the profiling. However, the maximum scope includes the basic domains which are necessary for understanding the concepts from the immediate scope. 
It's worth mentioning that ethical concepts have a binary nature, as they are actualized only being a part of a binary opposition. We suggest calling the cognitive trait of the antagonistic member of a binary opposition a benchmark, which acts as a domain with the opposite cognitive differential features. For instance, in order to understand the concept LIGHT, one must be aware of the concept DARK, which is absence of light, the concept CLEAN has its meaning only in the context of the domain DIRTY, etc. Therefore, the maximum scope of the conceptual base also includes benchmark reference field, which comprises domains, semantically and conceptually opposite to the domains from the immediate scope. Having outlined the terminological apparatus, we proceed to the methodology employed in the paper.

\section{3}

\section{METHODOLOGY}

The methodology of concept research in cognitive linguistics is aimed either at modelling its macrostructure (defining the cognitive traits that constitute sense, image and interpretational field of a concept) or building up matrix and frame models. A matrix model supposes unravelling all the conceptual background (domains) that serve as a reference frame for the concept. The connections in a matrix model between the domains are partitive, and thus a more general domain includes a more specific one and so on. A frame model reveals the connections between the concept and domains, which objectify its meaning. In this type of modelling the connections are called propositions (Zhabotynska 2009). The methodology used in this paper is aimed at establishing the connections between the cognitive features of the analysed ethical concepts (trajectors) with the cognitive features of their source etymological domains (landmarks) through the study of etymological meanings and images, which underlie target concepts' etymons.

The steps of the analysis are the following:

1. Determination of the main (nuclear) verbalizers of the concept (method of lexicographic analysis).

2. Analysis of the etymology of the verbalizer (method of etymological analysis) resulting in defining the basic representational field (domain / domains).

3. Establishment of the derivational path (method of cognitive analysis, method of trajector / landmark alignment).

4. Creation of the matrix model of the etymological profile of the concept.

5. Building up the edifice model of the analysed concepts.

It should be noted that for distinguishing purposes the names of the concepts are CAPITALIZED, lexico-semantic variant (LSVs) are given in "italics with double quotation marks" and cognitive features are given in 'single quotation marks'. 


\section{RESULTS}

\subsection{Profiling of the concept GOOD}

The concept GOOD is verbalized by the lexeme of the same name good, which originated from Old English gōd, meaning "entire, complete"; "desirable". Its Proto-Indo-European (PIE) etymon means "to unite, to be associated"; suitable" (Etymology Dictionary). In Old English (OE), for example, it was used in the sense like: Sio bip god to dolhsealfe (cit.ex Oxford English Dictionary) - [Water parsley is suitable for wound-salve poultice.] (Our translation is provided in []). Generally, the semantic evolution of the etymon can be represented by the chain: "entire, belonging together, united" - "suitable" - "desirable". The conceptual base, which underlies the current understanding has domains ENTIRE, SUITABLE, DESIRABLE, out of which ENTIRE is diachronically primary.

The profiling of the concept GOOD, in its ethical sense 'morally right', can be explained through the process of trajector / landmark alignment in the following way. The target profile feature 'morally right' was understood against the conceptual base represented by the domain ENTIRE. The trajector (the key cognitive trait of the concept GOOD) is 'being able to do positive things'. Diachronically it was understood against the reference frame ENTIRE with the landmark 'whole, belonging together', which is the most salient cognitive feature of this domain. Such a derivational path can be interpreted in the way that something positive and good in an abstract sense was understood in terms of something united and unsplit on the material level, for instance an unbroken or intact pot or a hand tool was perceived as a good one and as a result suitable for the use.

One should state that the conceptual base of the concept GOOD includes other domains along with the domain ENTIRE, and these are SUITABLE and DESIRABLE. The domain SUITABLE has the most salient cognitive feature of 'being suitable', which is the landmark (2) for the trajector 'doing positive things' of the profiled concept GOOD. It means that ability to do positive things was understood as a proper (suitable) feature or behaviour. Since people are intrinsically oriented towards doing good to themselves (the instinct of self-preservation), everything which is proper or suitable becomes an object of desire. This explains why the trajector 'doing positive things' aligns with landmark (3) 'being desirable'.

To summarize we posit that the path of conceptual derivation was complex. The trajector 'doing positive things' was understood against the three cognitive landmarks of the three domains, which are: landmark (1) - 'being united' (domain ENTIRE), landmark (2) - 'being suitable" (domain SUITABLE), landmark (3) 'being desirable' (domain DESIRABLE). Since the ethical sense of the concept was profiled against more than one landmark, we argue that in this case a process of conceptual assembly happened. The three abovementioned domains constitute the immediate scope of the conceptual base for the profiling of the ethical concept GOOD. 


\subsection{Profiling of the concept EVIL}

The ethical concept EVIL, which is defined as "something that is very bad or harmful" (Longman Dictionary) is verbalized by the lexeme evil and its synonym bad. The lexeme evil originated from Old English yfele "anything that causes injury, morally or physically" (Etymology Dictionary). For instance, OE: Ahab yfele weard beswicen [... was misled to his destruction] (Bosworth, 2014). Therefore, the profiling of the target ethical concept EVIL was carried out within the conceptual base, which includes domain INJURY. Injury is understood as a wound or damage and therefore regarded as something that splits the wholeness. Thus, the trajector 'being wicked' of the profiled concept EVIL is understood against the domain INJURY with the landmark 'something split or not united'.

This conclusion proves that the abstract idea of EVIL was conceptualized on the basis of concrete things. The conceptual base for its profiling is physical destruction or breaking (source domain INJURY). This means that the abstract idea of evil is anchored to concrete dissipation, destruction, dissemination or decay. Such a conclusion can be explained in the way that the most typical physical instances for evil are the decay of dead bodies or destruction of houses or other objects. The death of loved ones, the lack of a place to live or physical damage to valuable things are the worst examples of what could happen on a material level. As a result the metaphorical reinterpretation of physical damage or breakage, which are obviously considered bad, was generalized to abstract evil. Such a process of generalization can be called schematization of the prototypical situation from the material world, which triggered the appearance of the abstract concept.

The other synonymic verbalizer of the analysed concept is the word bad. This lexeme in diachrony had the following stages of semantic development: bad - "inadequate, unsatisfactory, worthless, wicked" originated from bæddel and its diminutive bæedling "effeminate man, hermaphrodite, pederast", for example in OE Wǽpen-wifestre vel scritta vel breddel [hermaphrodite or harlot or adulteress] (Bosworth, 2014). The etymon is related to bædan "to defile" (Etymology Dictionary). For example, in OE: Mǽru cwén bæédde byras geonge [the illustrious queen solicited her young sons] (Bosworth, 2014). Profiling of the meaning of the lexeme bad "morally wrong or evil" is also explained in terms of the cognitive operation of landmark / trajector alignment. The trajector of the profile is 'being wicked' (which is the same as for the verbalizer evil since they both objectify the same concept). In this situation though, the trajector is aligned with the two landmarks: landmark (1) 'being effeminate', which is based on the inner form of its direct etymon - bædling, and landmark (2) 'being defiled', which is based on the inner form of word bædan. We assume that 'being effeminate' was considered the worst trait for a man from a historic perspective, since such a man could not carry out the main biological and social functions that were expected of him - the continuation of his lineage and protection of his kin (as effeminate presumes "being weak"). In the process of conceptual mapping, 
based on schematization, the feature 'being effeminate' was generalized to 'anything inappropriate and wicked' in general.

Landmark (2) 'being defiled' comes from the meaning of the etymon bredan - "to defile", which means "to make something less pure and good", that is to spoil something. Thus, the concept EVIL was understood in terms of something that is physically unclean or spoilt. Therefore, the cognitive features 'physical uncleanness' and 'being spoilt' along with 'being effeminate' underlie the etymological imagery of the concept EVIL.

It should be noted that the concept EVIL was primarily profiled in the result of reinterpretation of the landmark 'split or broken', since 'being spoilt' can be prototypically understood as being broken. This is confirmed by the etymology of the word spoil - "to split, to break off' and by the central life experience: a broken cup, mechanism, weapon has always been considered "bad and inappropriate". The verb to defile is also used in relation to an inappropriate sexual act with a virgin, which might as well be understood as 'splitting' the woman's chastity, therefore the underlying landmark feature proves to be 'split'

\subsection{Profiling of the concept JUSTICE}

The concept JUSTICE is verbalized by the lexeme of the same name justice, which has three LSVs: 1) "the system by which people are judged in courts of law and criminals are punished"; 2) "fairness in the way people are treated"; 3) "the quality of being right and deserving fair treatment". LSVs (2) and (3) objectify the analysed ethical concept JUSTICE. The semantics of this lexeme verbalizes such cognitive features of the concept as 'being fair' and 'doing the right thing in relation to other people', which serve as trajectors in the process of JUSTICE profiling. In order to determine the primary conceptual base of JUSTICE, it is necessary to unravel the inner form of its verbalizers through the analysis of their etymology. As lexicographic sources prove, the two main verbalizers are justice and fairness.

According to the etymological data the lexeme justice derives from Latin iustus "upright, righteous, equitable; in accordance with law, lawful; true, proper; perfect, complete" (Etymology Dictionary). Consider some of the examples taken from the Glosbe Dictionary: Iustus societatis et Civitatis ordo fundamentale munus est rei politicae [The fair order of society and state is the main objective of politics] or In Evangelio apparet tamquam vir iustus, operosus, fortis [In the New Testament he looks as a truthful, diligent and solid man]; Venit, iustus metus [He is walking, that's perfect]; Rex iustus fuit [The King was fair]. Thus, we can single out a number of salient LSVs: "upright" (1); "true, equitable" (2); "proper" (3); "perfect, complete" (4); "in accordance with law" (5).

Before we hypothesized that abstract concepts, to which ethical concepts undoubtedly belong, were formed as a result of metaphorical reinterpretation of the concrete objects and phenomena of the objective reality. Hence, we posit that the first basic domain in profiling of the concept JUSTICE was the domain SPACE with the slot "Direction" (see 
LSV (1) “upright”). It's landmark (1) 'being vertical' was aligned with the trajector of the target concept JUSTICE 'being fair'. The cognitive transition from the straight, vertical direction to fairness is anchored to the experience of sensual perception of the physical world. As empirical data show, moving in a straight line is easier, safer and shorter than following a curved one, as the latter is geometrically longer and less safe, since curves restrict the vision. Moving in a straight direction, in contrast, gives more visibility and fewer opportunities for possible threats to hide. This claim is also linguistically proved, since there exist such expressions as to dodge the answer or to dodge the draft to the army, in which the literal meaning of dodge is to divert from the direct line of duty in order to avoid something.

The upright position also has a positive assessment in the context of the dichotomy 'earth and heaven', where the latter has the positive evaluation mark in mythological and religious epistemes. In the result of cognitive reinterpretation based on landmark / trajector alignment, the lexeme, which had already denoted "upright straight direction", was used to signify the new meaning "fairness". The landmark feature "upright straight direction' was understood as the quality of not hiding or keeping back anything and doing the right thing. Such ontological mapping expanded the use of the lexeme with a concrete spatial meaning - justice (in its etymological sense) to denote abstract notion of fairness.

LSV (2) "true, equitable" indicates that the analysed concept is also profiled against the domain TRUTH with the landmark 'being true', which is aligned with the trajector 'being right'. The profiling of the target ethical concept JUSTICE was carried out via the cognitive mechanism of specification when 'truth in general', landmark (2), transferred into the 'truth in people's relations' (trajector).

LSV (2) is closely connected with LSV (3) "proper". The latter actualizes the cognitive landmark trait 'acceptable' of the domain PROPER. The profiling of the target ethical concept was carried out via the cognitive process of specification, which correlated the cognitive traits of the domain PROPER that are 'proper, acceptable' with the trajector trait of the concept JUST 'being fair to people', therefore the meaning "proper" was narrowed to "proper treatment of people".

LSV (4) "perfect, complete" indicates that the conceptual base of JUSTICE comprises domain COMPLETE. The landmark for the ontological correspondence is the feature 'being united', which aligns with the trajector 'treating people fairly'. This posits that fair treatment was primarily understood in terms of completeness, which wasn't disturbed by anything, such as a lie.

Finally, LSV (5) "in accordance with law" actualizes domain LAW, which is also included into the conceptual base of the JUSTICE profile, since it is understood in the framework of LEGAL RELATIONS.

The other direct verbalizer of JUSTICE is its synonym fairness. From a diachronic perspective the meaning "pleasing to the sight, beautiful, handsome, attractive" is prior to the ethical meaning "morally good" (Etymology Dictionary). This means that the trajector 
'good morality' was understood against the landmark 'good appearance', which once again proves that understanding of a moral concept was originally anchored to the perception of the physical world (cf. to preserve one's face in the meaning "to preserve one's decency").

The etymological and cognitive analyses proved that profiling of the concept JUSTICE was carried out against the conceptual base which includes the domains SPACE, TRUTH, PROPER, COMPLETE, LAW, and BEAUTY. It should be mentioned that the domain SPACE with the landmark 'straight, upright' has the most concrete meaning, while the other ones bear a higher level of abstraction. Following the claim that abstract concepts derive from the concrete ones as a result of their metaphorical reinterpretation, one can conclude that the most basic domain is the concrete domain SPACE and the cognitive features 'direct' and 'upright' are the basic landmarks for the profile of the target concept JUSTICE.

\subsection{Models of GOOD EVIL and JUSTICE profiles.}

As the analysis revealed, the domains PROPER and COMPLETE underlie the profiles of both the concepts GOOD and JUSTICE. Profiling of JUSTICE coherent with GOOD proves that JUSTICE was understood with the positive evaluative mark, the same way as something complete as opposed to split or broken.

The profiles of the analysed concepts are given in the Table 1.

Figure 1. Matrix model of GOOD, EVIL and JUSTICE profiles

\begin{tabular}{|c|c|c|c|}
\hline Profiled concept & Trajector & Landmark & Domain \\
\hline \multirow[t]{3}{*}{ GOOD } & \multirow{3}{*}{$\begin{array}{l}\text { 'behaviour, attitudes, } \\
\text { forces etc. that are morally } \\
\text { right' }\end{array}$} & 'whole, belonging together' & ENTIRE \\
\hline & & 'suitable' & PROPER \\
\hline & & 'desirable' & DESIRABLE \\
\hline \multirow[t]{4}{*}{ EVIL } & \multirow{4}{*}{$\begin{array}{l}\text { 'being very bad and } \\
\text { harmful; } \\
\text { being inadequate, } \\
\text { unsatisfactory, worthless' }\end{array}$} & 'split or not united' & INJURY \\
\hline & & 'effeminate' & EFFEMINATE MAN \\
\hline & & 'physically unclean' & UNCLEANNESS \\
\hline & & 'being defiled' & DEFILEMENT \\
\hline \multirow[t]{7}{*}{ JUSTICE } & \multirow[t]{7}{*}{ 'being just or fair' } & 'vertical' & \multirow{2}{*}{ SPACE } \\
\hline & & 'direct' & \\
\hline & & 'true' & TRUTH \\
\hline & & 'suitable' & PROPER \\
\hline & & 'perfect, complete' & COMPLETE \\
\hline & & 'according to law' & LAW \\
\hline & & 'beautiful' & BEAUTY \\
\hline
\end{tabular}


The matrix model represents the results of trajector / landmark alignment indicating the ontological correspondences between etymological domains and their landmarks with the trajectors of the target concepts.

It should be mentioned though that some of the domains are not basic themselves, and thus they are understood against other domains. The full profile of the concept can only be revealed in the 'conceptual edifice' model, under which we understand the conceptual structure in which the target concept is profiled against non-basic domains, which are profiled against their own domains. If the latter are also non-basic, they are further profiled against other domains until the domains are basic, and thus their underlying etymological image equals the one on the synchronic language level. The conceptual edifice therefore consists of a number of layers.

The necessity to establish domains of the second order in a concept profile is prescribed by the laws of logic, the transitive property of equality in particular, which tells us that if $\mathrm{a}=\mathrm{b}, \mathrm{b}=\mathrm{c}$, then it follows that $\mathrm{a}=\mathrm{c}$. The profiling of a concept adheres to this principle as it is carried out on the basis of metaphorical resemblance, when the profiled concept $\mathrm{A}$ with the trajectors $\mathrm{a}_{1}, \mathrm{a}_{2}, \mathrm{a}_{\mathrm{n}}$ is correlated with the landmark concept $\mathrm{B}$ having the landmark features $b_{1}, b_{2}, b_{n}$. But when the concept $B$ itself is understood against its domain $\mathrm{C}$, $\mathrm{B}$ becomes a target concept itself in relation to $\mathrm{C}$ and $\mathrm{b}_{1}, \mathrm{~b}_{2}, \mathrm{~b}_{\mathrm{n}}$ become trajector features which are aligned with landmarks $\mathrm{c}_{1}, \mathrm{c}_{2}, \mathrm{c}_{\mathrm{n}}$. In this case $\mathrm{C}$ becomes a domain of the second order for the profiled concept $\mathrm{A}$, and $\mathrm{c}_{1}, \mathrm{c}_{2} \mathrm{c}_{\mathrm{n}}$ become landmarks of the second order. This hierarchy becomes evident when the results of the profiling of the concept are represented in the edifice model (see Model 1 "Conceptual edifice of the profiles of the concepts GOOD and JUSTICE").

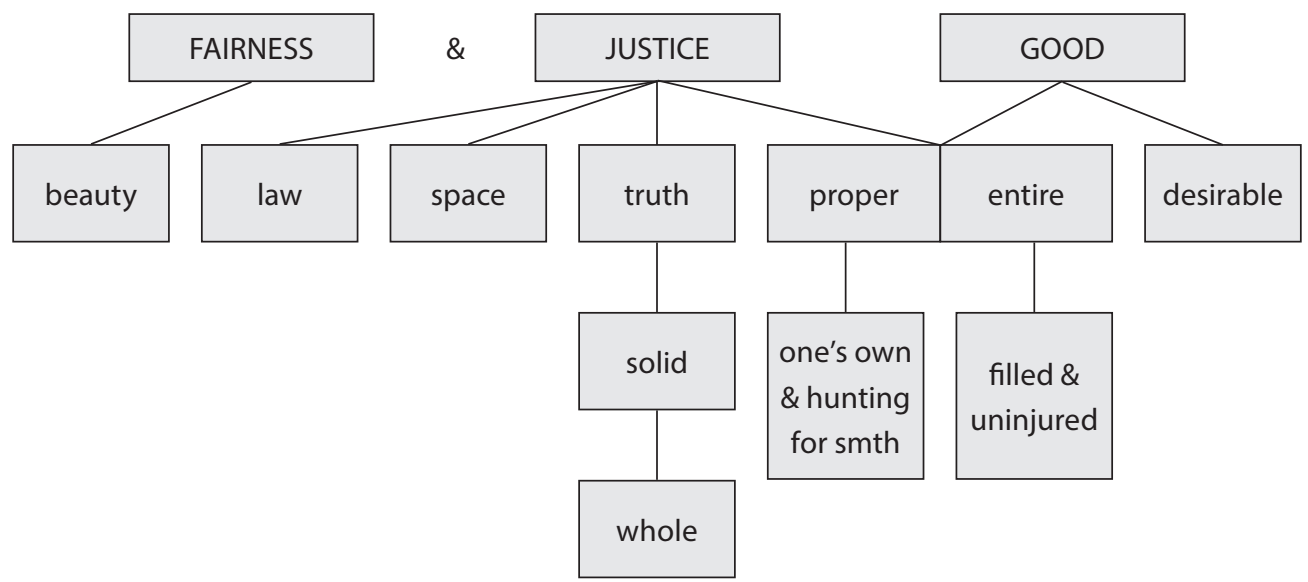

Model 1. Conceptual edifice of the profiles of the concepts GOOD and JUSTICE. 
The upper squares represent the names of the domains and the vertical dimension of the model shows the hierarchy among domains, in which the first layer represents the domains of the first order, the second layer the second order, etc.

This edifice model reveals that ethical concept JUSTICE is profiled against a number of domains which are physical, and thus based on the material environment (WHOLE, BEAUTY, SPACE), and ideal (TRUTH, LAW, SUITABLE). These domains constitute the surface layer of the conceptual edifice. The ideal domains though are non-basic and are profiled against other concepts, which objectify the concrete material things. For instance, TRUTH is understood against the concept SOLID. This can be explained by the fact that on the level of central life experience a solid surface is more secure and one can trust it as it won't break or make you sink. SOLID itself is understood against the etymologically more prior concept WHOLE. This is again explained by the basic experience of people dealing with material things. For example, a wall without cracks or uncleft plank are firmer than a cracked wall or plank.

The concepts PROPER \& SUITABLE are profiled against abstract ideas of 'owning something' and 'hunting for something to own it' correspondently. Hunting and appropriation are basic activities that humans once had to do in order to survive. As such, JUSTICE in the meaning of the 'proper' state of relations in society is primordially grounded on the 'proper' condition of the individual, which is attainable via 'hunting for' and acquiring the things necessary for survival and owning them.

Concepts with the abstract meaning WHOLE \& COMPLETE are understood against the concrete domains FILLED \& UNINJURED. On the basis of material experience something whole is something which does not lack anything (e.g. a wall with no missing stones), or something which is not damaged or injured (a shield without cracks or clothes without holes) that is 'filled' with all the necessary elements.

The cognitive features of the second order domains can also be viewed as second order landmarks of the profiled concepts GOOD and JUSTICE, as they can be considered as 'landmarks of the landmarks'

It should be noted that PROPER \& SUITABLE and WHOLE \& COMPLETE are the domains against which both ethical concepts JUSTICE and GOOD are profiled, which means that these concepts have the same conceptual base for their understanding as they have mutual connection. JUSTICE is undoubtedly considered to be good, while one of the most salient examples of GOOD in society is all-embracing JUSTICE.

A similar edifice model can be built for the antagonistic concept EVIL (see Model 2. Conceptual edifice of the profile of the concept EVIL).

The first order domains of the concept EVIL are INJURY, EFFEMINATE MAN, UNCLEANNESS and DEFILEMENT. All of them with the exception of EFFEMINATE MAN are not primary, and therefore are based on the domains of the second order. INJURY is profiled against BEING SPLIT, which proves that EVIL on the ontological level is diametrically opposite to GOOD. UNCLEANNESS is understood as an absence 


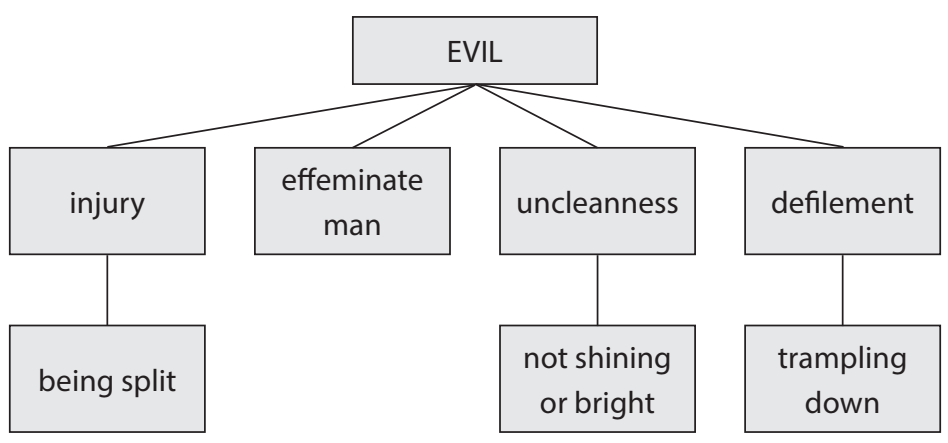

Model 2. Conceptual edifice of the profile of the concept EVIL

of shining, which is anchored to day-to-day experience, as dirty things are normally not bright. Defilement is perceived in terms of TRAMPLING DOWN, as treading upon something with one's feet is conventionally considered to be the sign of loathing. The second order domains trigger the second order landmarks in the profile of the concept EVIL and make up the maximum scope of the conceptual base.

\section{$5 \quad$ CONCLUSIONS}

Analysis of the process of concept profiling in terms of trajector / landmark alignment proves to be efficient, as it reveals the innate mechanisms of human cognition. Application of the described methodology makes it possible to trace the internal 'hidden' images of currently well-known and extensively used ethical concepts, which contributes to a deeper and more profound understanding of how humans perceive the world, and enables a deeper understanding of the concepts, which are used on synchronic level. The research into the etymological profiles of the focal ethical concepts carried out in this study proved that abstract things are primarily based on an understanding of material things. In other words, the 'literal' understanding of ethical concepts is rooted in the material central life experience of people. The results reveal that GOOD is understood as something whole and unsplit, EVIL as something split or injured, JUSTICE as something vertical and direct.

This claim confirms the apperceptive principle of cognition, which presupposes the use of metaphor and associations for the creation of mental 'bridges' between familiar concepts and new ones, which results in ontological mappings. From a lingual perspective the following form of cognition is depicted in the law of language economy, which is aimed at verbalizing similar things by the same nominative units, thus preventing uncontrolled inflation of the language lexicon. The results obtained in this paper can be useful not only for cognitive linguistics, but also for psycholinguistics, gnoseology and psychology itself, as they reveal the way humans categorize the world. The current paper 
made just the first attempt to employ the cognitive methodology of profiling in relation to ethical concepts GOOD / EVIL and JUSTICE, but further studies can carry out profiling of other ethical concepts, as well as any other abstract concept from our picture of the world.

\section{BIBLIOGRAPHY}

CHOMSKY, Noam (ed.) (1997) Language and Cognition. (The Future of the Cognitive Revolution). Oxford: Oxford University Press.

EVANS, Vyvyan/Melanie GREEN (2006) Cognitive linguistics: An introduction. Edinburgh: Edinburgh University Press.

FILLMORE, Charles (ed.) (1982) Frame semantics. The Linguistic Society of Korea (ed.), Linguistics in the Morning Calm. Seoul: Hanshin Publishing Co. 111-137.

GOLIANICH, Maria (2007) Inner form of the word and discourse. Ivano-Frankivsk: Prikarpatskiy National University Press.

GOLOVENKO, Kristina (2012) Inner form of the word as an imaginative feature. Kirovograd: Bulletin of Kirovograd National University.

LAKOFF, George (1993) The contemporary theory of metaphor. A. Ortony (ed.), Metaphor and Thought. Cambridge: Cambridge University Press, 202-251.

LAKOFF, George/Mark JOHNSON (2003) Metaphors we live by. Chicago: University of Chicago Press.

LANGACKER, Ronald (1987) Foundations of cognitive grammar. Theoretical prerequisites. Stanford: Stanford University Press.

LANGACKER, Ronald (2000) A course in cognitive grammar. Manuscript. Preliminary draft. San Diego: University of California San Diego Press.

POTEBNIA, Aleksandr (1993) Thought and language. Kiev: SYNTO.

ROSCH, Eleanor (1978) Principles of categorization. E. Rosch/B. Lloyd (ed.), Cognition and Categorization. Hillsdale: Lawrence Erlbaum Associates, 27-48.

SCRAGG, Greg (1976) Semantic nets as memory models. E. Charniak/Y. Wilks (ed.), Computational Semantics. Amsterdam: North Holland Publishing Co., 101-127.

SPHET, Gustav (2006) The Inner Form of the Word: Studies and Variations on Humboldt's Themes. Moscow: Kom-Kniga.

ZHABOTINSKAYA, Svetlana (2009) Concept / Domain: Matrix and Network Models. Culture of the peoples of the Black Sea region 168, 254-259.

An Anglo-Saxon Dictionary Online. 18. August 2021. https://bosworthtoller.com/. Etymology Dictionary Online. 15. August 2021. https://www.etymonline.com/. Glosbe Dictionary Online. 21. August 2021. https://ru.glosbe.com/la/ru/. Longman Dictionary Online. 13. August 2021. https://www.ldoceonline.com/. 


\section{POVZETEK}

\section{PROFILIRANJE ETIČNIH POJMOV DOBRO/ZLO IN PRAVICA Z ETIMOLOŠKEGA VIDIKA}

V prispevku predstavljamo poglobljeno analizo izzivov, ki jih prinaša profiliranje pojmov z določanjem etimoloških domen. Pri tem se osredotočamo zlasti na izzive, na katere smo naleteli pri profiliranju pojmov DOBRO/ZLO in PRAVICA. Za obravnavo teh pojmov smo se odločili, saj so glede na podatke iz korpusa British National Corpus med vsemi etičnimi pojmi deležni največje besedilne aktualizacije. Pri raziskovalnem delu smo se opirali na načela teorije konceptualnih metafor in na metodo uravnavanja trajektorija in orientirja, ki temelji na idejah jezikoslovca Ronalda Langackerja o profiliranju pojmov v jezikovnih izjavah. V prispevku predstavljena metoda profiliranja je novost na področju raziskovanja jezika, saj smo jo prilagodili analizi in pojasnjevanju imenoslovnih načel »prevajanja« abstraktnih etičnih pojmov v jezikovno obliko. Raziskavo smo zasnovali na predpostavki, da govorci abstraktne kategorije konceptualizirajo na podlagi življenjskih izkušenj in poznavanja konkretnega sveta. Izkušnje in konkretni pojmi tako tvorijo izhodiščne domene, na podlagi katerih nastanejo ontološke meddomenske preslikave v ciljno domeno abstraktnejših etičnih pojmov. S pomočjo raziskave etimonov izhodiščnih domen etičnih kategorij smo določili podobe, ki so bile podlaga za nastanek metaforičnih povezav med izhodiščnimi in ciljnimi pojmi. Določitev etimološke plasti leksikalizatorjev izhodiščne domene nam je omogočila opredelitev bistvenih psiholoških mehanizmov človekovega spoznavanja in dojemanja sveta. Ti temeljijo na prirojeni nagnjenosti človeškega uma k oblikovanju metaforičnih povezav med vsakdanjimi doživetji in kompleksnimi abstraktnimi idejami. Rezultati raziskave so nam omogočili izgradnjo matričnega modela analiziranih pojmov, ki smo ga nato nadgradili še $z$ večplastnim modelom »konceptualne zgradbe«. Ta prikazuje konceptualizacijske poti, po katerih človeški um razvršča in kategorizira abstraktne etične ideje.

Ključne besede: pojem, domena, orientir, profiliranje, trajektorij

\section{ABSTRACT \\ PROFILING OF THE ETHICAL CONCEPTS GOOD / EVIL AND JUSTICE FROM THE ETYMOLOGICAL PERSPECTIVE}

The paper gives a comprehensive insight into the peculiarities of concept profiling through defining the related etymological domains. The aim of the paper is to reveal the peculiarities of the profiling of the concepts GOOD / EVIL and JUSTICE through elucidating their source domains from an etymological perspective. The choice of the analysed ethical concepts is stipulated by their higher contextual actualization frequency, as compared with the other ethical concepts, according 
to the data obtained from British National Corpus. The research method of trajector / landmark alignment used in this work is based on R. Langacker's views on the profiling of concepts in language utterances and on the tenets of Conceptual Metaphor Theory. The novelty of this approach consists in the fact that it was elaborated and tailored for the analysis and explanation of the onomasiological principles of 'wrapping' abstract ethical concepts into the language form. The underlying idea is that abstract categories were conceptualized on the basis of background central life experience and knowledge of concrete things. It is argued that such things were the source domains in ontological cross-domain mappings for the target ethical concepts. The current research into the source domain etymons of the ethical categories made it possible to determine the underlying images, which are the core for drawing metaphorical correspondences between source and target concepts. The etymological layer of source domain lexicalizers revealed the intrinsic psychological mechanisms of human cognition and perception of the world, which consist in the inherent proclivity of the human mind to make metaphorical parallels in the direction from daily, central experience to complex abstract ideas and notions. The results made it possible to develop the matrix model of the analysed concepts, which was further developed into a 'conceptual edifice' multi-layer model, which reveals the conceptualization paths along which the human mind classifies and categorizes abstract ethical ideas.

Keywords: concept, domain, landmark, profiling, trajector 